\title{
The Concentration of Capital as a Reason for the Accelerated Development of the Economic System
}

\author{
Eugene Titenko* , Olga Korneva ${ }^{\mathrm{a}}$ \\ * Corresponding author: Eugene Titenko, titenko@sibmail.com \\ ${ }^{a}$ National Research Tomsk Polytechnic University, 30 Lenin Ave., Tomsk, Russia, titenko@sibmail.com, +79039147899
}

\begin{abstract}
http://dx.doi.org/10.15405/epsbs.2016.02.60

Recently, much attention is paid to the relationship of accelerated development of the economy and the growth of the welfare society, assessment and factors influencing its development. Concentration of resources and capital is the starting point of accelerated economic development. At the same time the dominance of any form of capital available. The successful combination of the names of all forms of capital leads to the emergence of innovation, which in turn contribute to the development of not only the production sector, but also the economic system as a whole at a faster pace. This increases the quality of life and increasing well-being of the population.
\end{abstract}

(C) 2016 Published by Future Academy www.FutureAcademy.org.uk

Keywords: Capital, human capital, economic development, rapid economic development, competitiveness and well-being.

\section{Introduction}

Any economic system is the gradual development. In recent studies there is increasingly talking about the trend accelerating succession of stages. It allows scientists to judge the phenomenon as economic contraction time. The study of this process will identify the causes and factors as well as methods of controlling this process.

In the article «The Transformation of civilizations in time» (Titenko E.A., 2013) it was proved that any approach to a certain stage, a period of economic development from the perspective of evolutionary criterion whether formational, stadial or civilizational observed shortening of the period of existence of civilization. It was clearly presented the process of compression not only historical, but also the economic time.

In this study, we attempt to identify factors that influence the accelerated development of the economic system. 
Concentration of resources and capital is the starting point of accelerated economic development. At the same time, there is no dominance of any form of capital. The successful combination of all forms of capital leads to the emergence of innovation, which is pushing the development of not only the production sector, but also the entire economic system at a faster pace.

In the literature there are lots of interpretations of the term «economic development». A number of authors agree on the opinion that economic development is characterized by an increase in income per capita and as a consequence of improved quality of life. Economic development can also be judged by the cyclical nature of the economy, the progress and evolution. Another group of authors tend to associate economic development with profound changes in all spheres of life: economic, technical, political and institutional. In this case, capital, natural resources and labor are the dominant factors of production.

Fillipenko A.S. analyzes the concept of economic development, concludes that «common to all approaches is that, in spite of numerous quantitative and qualitative changes, any organic system finds its own identity and committed to preserving the integrity of the development process.»

Meaning of the term «economic development» in contemporary sources is revealed by comparing it with similar categories and processes.

Quite often, this term is equated with economic concepts: «progress» and «modernization».

Widespread interpretation of «progress» is to determine its «as the type or direction of development, which is characterized by a transition to more mature state of the object.» (Kononov A.A., 2005)

Modernization - is «a set of interrelated processes of capital accumulation (resource mobilization), the development of production and productivity, etc.» ( Kononov A.A., 2005). Also modernization associated with changes in the economic, technical, technological, political, social and cultural spheres of society. Nowadays modernization often associated with changes not only in the economic but also technical, technological and socio-cultural spheres of society.

In this case, modernization is associated with the transformation of society from traditional to modern.

The concept of «development» in the literature also replaces the term «evolution». Evolution is social changes conducted on general principles. For the evolutionary process is characterized as a quantitative and qualitative improvement. Evolution is a process that takes place in itself and, therefore, it is a kind of development. Several authors say about the difference between evolution and development. In fact the evolution reflects the changes and superficial nature of the action and development is deep transformations that lead to a radical restructuring of functional objects and their components.

Also we shouldn't forget about such categories as «economic growth». Often this concept put on a par with the «economic development».

J. Schumpeter (1982) was the first who defined the difference between economic development and economic growth: the first implying primarily qualitative changes inherent economic circuit and the other one is the usual increase in population and wealth. Economic growth is a quantitative economic development and economic development is a quality economic growth. 
From the foregoing, it must be concluded that «economic development» is not only the expansion of production, but its complication and differentiation. Economic development involves working behavior as the introduction of new technologies in the economy based on a perfect education, infrastructure and institutions. In this way, the «economic development is a systematic, long-term improvement and mass of material and spiritual living conditions of people on the basis of productivity of labor and capital». (Vertakova 2005)

P. Hawken (2002) defines capital as accumulated wealth in the form of investments, factories and equipment. And distinguishes four types of capital:

- Human capital as the form of labor, intelligence, culture and organization;

- $\quad$ Financial capital, which consists of cash, investments and monetary relations;

- $\quad$ Production capital, which includes infrastructure, machinery, tools and factories;

- Natural capital, which composes of resources, living systems and capabilities of ecosystems.

Today we can certainly say that Karl Marx is the founder of the modern theory of capital. He argues that the starting point is the capital of commodity circulation. Marx reveals the content of the genesis and function of the category «capital».

1. Capital is a specific economic category of capitalism, which reflects the content of the social relations of production method.

2. Capitalist society is due to a set of bourgeois relations of production, primarily property relations.

3. The basis of the capitalist mode of production is a «product of the preceding process» which was formed in the womb of feudalism. According to Marx, this period is the «era of primitive accumulation of capital», which separates the working conditions from the producers. It was typical for the XVIII century in England.

4. The motive of capitalist production is the production of surplus value.

5. Production of the surplus product is the main production function of capital.

The most important point of the Marx's Capital theory is the concentration of capital. «... It is the accumulation of large capital by destroying small - a form of the process that makes the working conditions in the capital and some capital on a larger scale, finally separates the capital, formed in many areas of society, from their owners and centralizes them in the hands of the big capitalists.»

Concentration and accumulation of capital leads to an increase in the power of capital. Capital has a higher social force. It ensures the development of the productive forces and economic growth. Marx said that «At a corresponding industrial struggle of the nations in the world market everything depends on the rapid development of capital.»

The modern theory of capital offered by Kamenetsiy V.A. He treats capital as «a set of benefits available for the person (or which it may be used) and which constitute the natural energy in various forms, human abilities (knowledge, quality) and hard work and intelligence, which means employment benefits, previously made by man in the form of tangible assets, resources and information». It means that the term of «capital» is multifactorial. Kamenetskiy V.A. identifies three groups of factors, each of these has its own characteristics: 
1. Natural capital - natural resources, various energy measures, including solar and other forms of energy, land, water and air, as factors of life support existing flora and fauna.

2. Human capital - the skills and qualities that a person has. Human capital is also natural capital. But the reason for its selection as a separate type of capital is the intellectual abilities that no one other than the person possesses.

3. The results of labor and intellectual property rights are the means of production, production infrastructure, the accumulated amount of information, public institutions, which greatly increase the efficiency of the labor process.

Table 1 - Development of capital as a factor of production in the context of the evolution

\begin{tabular}{|c|c|c|c|}
\hline $\begin{array}{l}\text { Factor / type of } \\
\text { society }\end{array}$ & Preindustrial & Industrial & Postindustrial \\
\hline natural capital & $\begin{array}{l}\text { Stocks of wildfowl } \\
\text { and plants }\end{array}$ & $\begin{array}{l}\text { Game reserves of } \\
\text { plants } \\
\text { Stocks of raw } \\
\text { materials }\end{array}$ & $\begin{array}{l}\text { Game reserves of plants } \\
\text { Inventories of raw materials } \\
\text { are depleted }\end{array}$ \\
\hline human capital & $\begin{array}{l}\text { Minor rudiments of } \\
\text { knowledge } \\
\text { Only manual labor }\end{array}$ & $\begin{array}{l}\text { Growing a layer of } \\
\text { teachers and } \\
\text { scholars. They are } \\
\text { the bearers of } \\
\text { human capital }\end{array}$ & $\begin{array}{l}\text { There is an accumulation of } \\
\text { knowledge, skills and } \\
\text { experience. Science is the } \\
\text { backbone factor. Education } \\
\text { throughout life. }\end{array}$ \\
\hline $\begin{array}{l}\text { The results of } \\
\text { labor and human } \\
\text { activity }\end{array}$ & $\begin{array}{l}\text { Instruments of labor } \\
\text { by the end of the } \\
\text { period at a } \\
\text { sufficiently high } \\
\text { technical level }\end{array}$ & $\begin{array}{l}\text { Using of } \\
\text { increasingly } \\
\text { complex and } \\
\text { sophisticated } \\
\text { technology. } \\
\text { Machines replaced } \\
\text { the primitive manual } \\
\text { labor }\end{array}$ & $\begin{array}{l}\text { The rapid growth of high- } \\
\text { tech products }\end{array}$ \\
\hline Source: compiled & he authors & & \\
\hline
\end{tabular}

In this way, as a result of the transformation process the human capital is a major factor in economic growth.

For the most developed countries in the world today there is transition to a post-industrial society. This is due to the growing trend of increasing the role and importance of knowledge, scientific discoveries and innovations.

At this time when traditional resources are close to exhaustion, they are replaced by innovative resources held by a man. Therefore, in the present conditions there is a growing role of a man capable to analyze, synthesize and create a new one.

This confirms the global economic history.

It is considered that the transition to industrialization begins in England in the XVIII century. In that period the transformation of economic relations under the influence of several factors:

1. Agrarian reforms. It is believed that after the agrarian reform it begins capitalization of England. There were all the conditions for capital accumulation, due to liberal policies in the field of agriculture.

2. The expansion of foreign trade. In addition to the agrarian sector it is liberalized foreign trade. England carried out foreign trade at the expense of their colonies. Mineral resources of the colonial countries were an important factor in the industrial development of England. 
Thus, the primitive accumulation of capital by the middle of the XVIII century allowed to launch the rapid development of capitalism. It was created by the labor market, expanding the boundaries of the internal market, and there is a further accumulation of capital. It ensured continuous development of manufactories, which created the preconditions for the transition to machine production. It bore for a specialization and division of labor, simplifying work processes. It is considered that it was exactly the time when the industrial revolution in England began.

Innovative solution of the transformation process was the invention of the loom and the steam engine.

In 1785, E. Cartwright loom was invented. The main advantage of the introduction of this innovation is the work of one machine was equal to the work of 40 workers. Moreover, the use of machines was not limited to textiles. The machine began to be used in cloth devision, silk weaving and the manufacture of linen.

Another example that reflects the innovative transformation of the socio-economic system is the invention of the steam engine in 1784 by Watt. Innovation rapidly implemented in all sectors of the economy, down to the coal and steel industry.

After the steam engine in 40 years the transport problem has been solved. The first railroad was built. These are examples of global innovative solutions.

As opposed to other countries, the industrial revolution in England had a very fast pace. The reason was a very high concentration of production and capital in the country.

Reducing the rate of industrial development accounts for the 70th of XIX century. This is primarily due to the expansion of the domestic market and a large export of capital abroad. The concentration of capital began to fall.

Let's study the main features of industrial society:

1. The development of techniques and technology through the use of the production of scientific knowledge. In the XVIII century there was formed the union of science and industry, and in the XIX century it was finally issued, laid the foundation for rapid development of production.

2. The result of the union of science and industry are the industrial revolution, which significantly changed the relationship between man and nature, man's place in the production system.

3. Due to the development of technological civilization accelerated update artificially created human subject protection. We are talking about mechanical transport, household appliances.

4. Along with the technological civilization in production implemented corporate collectivism. Interdependence of people is due to the division of labor in the production cycle. Manufacturing organizations and corporations (factories, etc.) began the leading form of social organization.

5. In addition to the corporate collectivism group develops and class consciousness. Formation of private capitalist relations led to the differentiation of society.

Thus, the world is undergoing radical changes, especially in the economic sphere. The industrial revolution made it possible to solve the problem of hunger, as machine production work on mass consumption. Life expectancy dramatically increased. With the achievement of material well-being, 
with the advent of the abundance of production, clothing, footwear, household appliances, market economy has spread around the world. Market economy is characterized as oriented to the consumer. Market is a regulator of social production and universal value.

In general, the market economy can be considered as an achievement of industrial civilization. This is the most effective of all existing forms of organization of social production and human value.

Due to the development of market relations and increase productivity one can observe the next stage of the transformation process. There is a gradual outflow of labor from the industrial sphere to the service sector. This was one of the prerequisites for the transition of a qualitatively new state, namely the transition to a post-industrial society.

Zherebin V.M. (2008) says about postindustrial society as a society where the economy as a result of the technological revolution and significant income growth priority moved from the production of goods mainly to the production of services. The dominant production resources are information and knowledge. Research and development are the main driving force of the economy. The most valuable features are the level of education, professionalism, creativity, learning and employee.

One of the most common definitions consider the definition of D. Bell, «post-industrial society is a society where the economy has moved from the pre-emptive priority production of goods to production of services, research, organization of education and quality of life; where the class of technicians has become the leading professional group and most importantly where innovations ... are increasingly dependent on the achievement of theoretical knowledge ... ... post-industrial society. Suggests the emergence of the intellectual class, whose representatives at the political level act as consultants, experts and technocrats.»

This term caught on fairly quickly in the scientific community. Daniel Bell argued that if countries with different social systems can be defined as «industrial society», the economy is based on mining industry, rather than producing can be classified as a «pre-industrial», therefore, changes in the nature of technology and allow us to speak of a "post-industrial economy». The basic premise of postindustrianolizma was the decision of the conflict between workers and employers. The solution of this conflict was described by Haytun S.

Until the mid XX century, it was believed that employers pay employees a little more profitable and a large part of the income to keep them. This leads to stratification of the population into rich and poor, which caused social conflicts. The problem could not be solved as long as the switch from a microeconomic level to macroeconomic. The solution is as follows, the employees are primarily buyers. Poor buyers purchase fewer goods; rich buyers purchase a lot, thus bringing more income to the employer.

Thus, there is an accumulation of capital and efficient redistribution. Thus embarked on a new Keynesian economics. History shows that the transition to the Keynesian model of development could be carried out only those countries that have achieved high economic - industrial - level of development.

The result of the chosen course of Western countries in the 1960 - 1970 is a post-industrial society.

S. Haytun identifies five signs of post-industrial civilization: 
1. Scope of services exceeds the share of GNP in material production. With the extra money consumers are buying more and more services that promote the development of the service sphere;

2. Knowledge is becoming the decisive factor of production. High-tech industry is developing very fast. Increases the welfare of society that creates demand for higher education. Sharply increased growth of birth innovations that accelerate the transformation of the system;

3. There is an explosion of high technology. In consequence of the growth of the welfare of workers and the increasing demand for higher education is the development of high technologies. There is a modernization of production;

4. There is the information revolution. Knowledge plays a central role in the post-industrial society. Information is becoming the main resource. During the period of post-industrial development occurs the information revolution.

In support of this theory there is the research of the propagation velocity of information and computer technology in the world spent Krasilnikova E.V. (2001).

Table 2 - The rate of spread of information and computer technology in the world

\begin{tabular}{llll}
\hline technology & year invention & $\begin{array}{l}\text { Year when technology } \\
\text { began to use } 10 \% \text { of the } \\
\text { world's population }\end{array}$ & $\begin{array}{l}\text { The number of years it } \\
\text { took to reach } 10 \% \text { of } \\
\text { users }\end{array}$ \\
\hline phone & 1876 & 1989 & 113 \\
TV & 1923 & 1970 & 47 \\
personal Computer & 1977 & 2003 & 26 \\
cell phone & 1985 & 2000 & 15 \\
Internet & 1986 & 2002 & 16 \\
\hline
\end{tabular}

The following table illustrates the avalanche increase use of information and computer technologies in the world.

5. Paramount importance is the human capital. Traditional resources go by the wayside.

Table 3 - Transformation of the factors of production due to the development of human capital

\begin{tabular}{|c|c|c|c|}
\hline factors & category & industrial society & postindustrial society \\
\hline \multirow{6}{*}{ 종 } & process & $\begin{array}{l}\text { Takes place only between } \\
\text { man and nature }\end{array}$ & $\begin{array}{l}\text { Occurs only in the context of mental } \\
\text { activity Dependent on the knowledge, } \\
\text { skills and ethical rules }\end{array}$ \\
\hline & activities & Simple and complex. & Creative, \\
\hline & & Physical and mental & resourceful character \\
\hline & shape & workforce & Educational resources \\
\hline & & & Intellectual resources \\
\hline & $\begin{array}{l}\text { Relationship } \\
\text { with other } \\
\text { factors }\end{array}$ & $\begin{array}{l}\text { Independent component } \\
\text { production }\end{array}$ & $\begin{array}{l}\text { Inseparable from entrepreneurial ability } \\
\text { Appears human capital }\end{array}$ \\
\hline \multirow{3}{*}{ : } & object & $\begin{array}{l}\text { means of production } \\
\text { fictitious capital }\end{array}$ & financial \\
\hline & shape & material form & intellectual \\
\hline & & & human \\
\hline
\end{tabular}




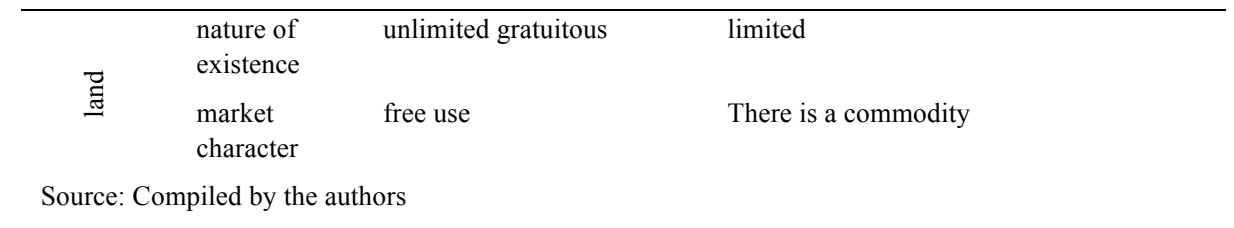

Based on the foregoing, it is worth noting that, moving from one level of development to another, the system undergoes a series of changes.

With the transition to the industrial development path system acquired:

1. The development of machine production, which allowed to go to the mass production of goods.

2. Unleash manual labor, thereby creating free time for self-development that improves the quality of life.

3. Development of the corporate world, so that there is a gradual transition to a market economy. Market economy is primarily a competition that promotes higher standards of living.

With the transition to a postindustrial society also continues to be released free time. There is a growing proportion of people with higher education. Rapidly developing science and as a consequence there is an explosion of high technology. The process of creation and dissemination of innovative technologies is accelerating. The main impetus for the transformation of the economic system is the concentration of capital in all its forms. For each stage is characterized by the accumulation of certain types of capital, the high concentration which leads to accelerated development.

Today the pace and efficiency of economic development are increasingly determined the accumulation of human capital.

Skoblyakova I.V. (2006) argues that the quality of human capital and the extent of its involvement in social production have a direct impact on the level of national wealth. Volume and structure of the national wealth is one of the main characteristics of the development of society, determine the economic strength of the country. The structure of the aggregate capital, taking into account the investments in physical and human capital, has changed dramatically in recent years.

Confirming this trend, it is based on the statistics given by Melyantsev V (2000).

\begin{tabular}{llll}
\multicolumn{4}{c}{ Table 4 - Changes in the structure of the total capital of the world (\% of total) } \\
\hline & 1913 г. & 1950 г. & $1997-1998$ г. \\
\hline physical capital & $67-69$ & $52-53$ & $31-33$ \\
human capital & $31-33$ & $47-48$ & $67-69$ \\
\hline
\end{tabular}

World Bank staff John. Dixon and K. Hamilton, an attempt was made to determine the structure of wealth attributable to one person in different countries. This approach to the definition of wealth is composed, according to the authors, from human resources, productive assets and natural resources.

Table 5 - Dimensions and structure of national wealth 
http://dx.doi.org/10.15405/epsbs.2016.02.60

eISSN: 2357-1330 / Corresponding Author: Eugene Titenko,Email: titenko@sibmail.com

Selection and peer-review under responsibility of the Organizing Committee of the conference

\begin{tabular}{|c|c|c|c|c|c|c|c|}
\hline Country, region & $\begin{array}{l}\text { All the } \\
\text { wealth }\end{array}$ & $\begin{array}{l}\text { human } \\
\text { resources }\end{array}$ & $\begin{array}{l}\text { production } \\
\text { assets }\end{array}$ & $\begin{array}{l}\text { natural } \\
\text { resources }\end{array}$ & $\begin{array}{l}\text { human } \\
\text { resources }\end{array}$ & $\begin{array}{l}\text { production } \\
\text { assets }\end{array}$ & $\begin{array}{l}\text { natural } \\
\text { resources }\end{array}$ \\
\hline & \multicolumn{4}{|c|}{ Dollars per capita } & \multicolumn{3}{|c|}{$\%$ Of total wealth } \\
\hline North America & 325274 & 247892 & 61953 & 15429 & 76 & 19 & 5 \\
\hline $\begin{array}{l}\text { Japan, } \\
\text { Australia, new } \\
\text { Zealand }\end{array}$ & 302389 & 205156 & 89786 & 7447 & 68 & 30 & 2 \\
\hline Western Europe & 236164 & 175570 & 54990 & 5604 & 74 & 23 & 3 \\
\hline Middle East & 146243 & 55898 & 27304 & 63041 & 38 & 19 & 43 \\
\hline South America & 94086 & 69548 & 15872 & 8666 & 74 & 17 & 7 \\
\hline Caribbean & 47338 & 32429 & 9863 & 5046 & 68 & 21 & 11 \\
\hline West Asia & 46076 & 35207 & 7220 & 3649 & 76 & 16 & 8 \\
\hline $\begin{array}{l}\text { Western and } \\
\text { Southern Africa }\end{array}$ & 29863 & 13231 & 4097 & 4708 & 60 & 19 & 21 \\
\hline
\end{tabular}

Thus, Skoblyakova I.V. (2006) identifies three groups of countries. «The first group is a preindustrial economy with a total wealth per capita of less than $\$ 3,000$., a relatively low proportion of human resources and a relatively high share of natural resources in the form of agricultural land (65\% and $10-20 \%$ ). The second group is the countries that are at different stages of industrial development, the level of wealth per capita of US $\$ 45,000$ to 95,000 ., A specific gravity of human resources from 68 to $79 \%$, industrial resources about $15-25 \%$, and natural resources from 5 to $12 \%$. The third group of countries is highly industrialized countries in the transition to post-industrial development. They are characterized by the level of aggregate wealth in excess of $\$ 235,000$. Per capita, with the share of human resources in excess of $74 \%$, industrial resources in the range of $20-30 \%$ and natural resources less than $5 \%$. The groups generally correspond to the metaphorical picture painted E. Tofflerom three waves of human development (agrarian society, industrial and postindustrial)».

We need to noticed that most countries nowadays live in the «first wave». Here come to the fore the problem of overcoming poverty and hunger. Highly developed countries are adrifted by «second wave». And only a few country leaders are on the rise «third wave». (Olga Fedotova, \& Elena Platonova, 2014)

\section{Conclusion}

Accordingly, the behaviour of the state should focus on investing in human capital and increase the return on such investments. Increased investment in human capital like a ripple effect will lead to an increase in the quality of human capital, which will be reflected in an increase in productivity, strengthening the scientific and technological orientation of production.

The main task of any state is to improve the quality of capital. It will inevitably lead to the growth of economic efficiency, which is affect the level of national income and as a result will lead to the improvement of the quality of consumption and living conditions. Increase the quality of satisfying the material and non-material needs, increased leisure time and wealth interests. Exactly these indicators will characterize the quality and efficiency of economic growth. 
In the area where capital is accumulated, there is the emergence of innovations. The innovative method out of the transformation crisis is the most loyal and fast. Through innovation, developing technology, new resources, developing competition and improved quality of life.

\section{Acknowledgements}

This work was performed by the authors in collaboration with Tomsk Polytechnic University within the project in Evaluation and enhancement of social, economic and emotional wellbeing of older adults under the Agreement No.14.Z50.31.0029.

\section{References}

Titenko E.A. (2013) Transformation civilizations in time. Economics and Entrepreneurship. 11,87-193

Filippenko A. (2001) Economic development. Civilizational approach, Moscow: Economics, 261p.

Kononov A.A. (2011) Management of structural transformation in the economy of the region: abstract dissertation of candidate of economic sciences: Kursk.

Schumpeter J.A. (1982) The Theory of Economic Development. M .: Progress.

Vertakova V. (2005) Indicative management of sustainable development of regional economic complex: dissertation of candidate of economic sciences: Kursk.

Hawken P. (2002) Natural Capitalism; Gathering the industrial revolution: first. from English. / P. Hawken, Lovins E., H. Lovins. Moscow: Nauka,

Marx, Capital. Available at: http://anticapitalist.ru/books/kapital.pdf

Protopopova N.I. (2009) Categorical notion of "capital": features private capital in modern Russia. Bulletin of the University of Tambov. Series: the humanities. 12, 26-31

Kamianiec V.A. (2006) Capital (from simple to complex) / VA Kamenetz, VP Patrickeyev. - M .: ZAO "Publishing house" Economy "

Zherebin V.M. (2008) Russian society in the paradigm of post-industrialism / Economic science in modern Russia. 4, 41-54.

Bell D. (2001) FUTURE postindustrial society Sample social forecasting. Trans. from English. Ed. V.L. Inozemtseva. Moscow. Available at: https://bookmate.com/reader/an2x1EUC

Krasil'nikova E.V. (2011) System attributes of the Internet economy. Proceedings of the Saratov University. Series economy. Management. Really, series 1.11,32-38.

History of Russia (Russia in world civilization): Lectures / Comp. and holes. Editor AA Radugin. M .: Center, $2001 .$.

Skoblyakova I.V. (2006) Criteria for development of post-industrial society and the role of human capital. Managing social and economic systems. 1, p.12

Hiroki Iwamoto, Masako Takahashi. (2015) A Quantitative Approach to Human Capital Management. Procedia Social and Behavioral Sciences, 172, 112-119.

Abdulsalam Abubakar, Salina HJ. Kassim, Mohammed B. Yusoff. (2015) Financial Development, Human Capital Accumulation and Economic Growth: Empirical Evidence from the Economic Community of West African States (ECOWAS). Procedia - Social and Behavioral Sciences, 172, 96-103.

Olga Fedotova, Elena Platonova. (2014) Contemporary Politics of Russian Universities in the Development of Human Capital: The New Organizational Platform and Role of the Initiative. Procedia - Social and Behavioral Sciences, 141, 1177-1181 